\title{
Rib/snook design in mechanised depillaring of rectangular/square pillars
}

Rajendra Singh $^{\mathrm{a}^{*}}$, Ashok Kumar ${ }^{\mathrm{a}}$, Arun Kumar Singh ${ }^{\mathrm{a}}$, John Coggan ${ }^{\mathrm{b}}$ and Sahendra Ram ${ }^{\mathrm{a}}$

${ }^{a}$ CSIR-CIMFR (Council of Scientific and Industrial Research-Central Institute of Mining and Fuel Research), Barwa Road, Dhanbad, 826001, Jharkhand, India.

${ }^{\mathrm{b}}$ Camborne School of Mines, University of Exeter, Cornwall Campus, Penryn, Cornwall, UK TR10 9 FE.

* Corresponding author: Telephone: +91 326 2293269, Fax: +91 326 2296043/2296033, E-mail address: rsingh1_2@yahoo.com (Rajendra Singh)

\section{Abstract}

A field study at different mechanised depillaring (MD) operations in Indian coalfields (with depth ranging from 60 to $377 \mathrm{~m}$ and caveability Index variation from 2300 to 10500) found mixed performances of adopted sizes of the ribs/snooks. Formation of an irregular shaped rib/snook during MD of the existing square/rectangular pillars by a continuous miner and uniqueness of the existing geo-mining conditions limit scope of application of the conventional rib/snook design approaches. Taking guidance from the field studies, a parametric investigation is conducted in laboratory on the calibrated simulated models using FLAC $^{3 \mathrm{D}}$. An analysis of stress redistribution for different stages of the MD in simulated models provided a different characteristic of an irregular shaped ribs/snooks failure. Presence of moderate roof strata is found to be, relatively, more significant for the rib/snook design. Based on the simulation results, an attempt is made to provide a model for the rib/snook design in MD.

Keywords: Rib/snook, Depillaring, Continuous miner, Area based design, Simulation.

\section{Introduction}

Existing facts and figures about different developed coal seams (standing on pillars) find depillaring as a vital extraction technique [1] for the Indian coal mining industry. The industry has adopted large scale semi-mechanized depillaring operations (using drilling and blasting for coal winning and equipment, such as Side-Discharged-Loaders/Load-HaulDumpers for coal haulage) with the help of indigenous resources only [2]. However, the industry finds this depillaring approach challenging [3] for further improvements in production, productivity and safety. A mechanised depillaring (MD) operation (using a continuous miner (CM) for coal cutting and shuttle/ram car for fast coal haulage) possesses good potential for improved performance of the underground pillar extraction. The Indian coal mining industry introduced a MD operation in February, 2003 [4] and since then; at 
least, six different coal mines [5] have used this approach for fast underground pillar extraction. On an average, each of these MD operations produced around $2000 \mathrm{t}$ of coal per day and the observed goaf velocity (pace of extraction) approached close to $1.0 \mathrm{~m}$ per day. Most of these MD are adopted for the developed coal seams, where the existing widths (nearly $4.2 \mathrm{~m}$ ) of galleries are widened to $6.6 \mathrm{~m}$ to suit the machine movement. As the Coal Mines Regulations (CMR) of India provides, relatively, larger size of pillars therefore the existing pillars are, generally, split before slicing. Here, the line of pillar extraction is ideally kept straight or linear. But, due to the machine maneuverability limitations, the existing square and rectangular shaped pillars produce irregular shaped ribs/snooks against the goaf. The resulted irregular shape of a rib/snook (Fig. 1) makes compliance with the required linear design difficult.

The risk of goaf encroachment during slicing of a fender (split part of a pillar) is overcome by leaving a rib against the goaf (Fig. 2). Again, final slicing in a fender of the pillar is done ahead of four/three way intersections of the galleries. Here, the role of size/shape of the most out-bye rib (also called snook), to be left against surrounding galleries intersections, becomes vital for the safety of a depillaring operation [6]. Potential falls of competent roof inside the goaf during the depillaring operation or encroachment into the working area should be avoided [7]. Such an attempt of encroachment gets support from the inherent existence of different openings along the goaf line of a depillaring panel. To restrict such an encroachment, an effective support system is erected in these openings along the goaf line (generally called goaf edge support). All these openings, along the goaf edge, are supported by the roof bolt based breaker line support (RBBLS)[8]. Different field studies by CSIR-CIMFR found that the RBBLS works effectively during the depillaring under the shadow of stable rib/snook/fender only [9]. Therefore, the design of a rib/snook becomes an important component of the MD operation.

A rib/snook is a temporary natural support and should be sufficiently large to protect the slicing from goaf and surrounding gallery intersection. But, at the same time, the rib/snook should be small enough so that they do not inhibit the caving of roof strata inside the goaf with an advance of the working. Design of a rib during conventional depillaring is performed as per Directorate General of Mines Safety (DGMS) circulars. But use of this design approach is complicated for MD operations, for the following four reasons: (1) irregular shape of rib/snook, (2) straight line of extraction, (3) fast rate of extraction and (4) application of high capacity, pre-tensioned, stiff and resin grouted roof bolts as support system. A number of previous studies are reported [10][11] [12] for the design of a rib/snook 
in MD. However, the applicability of these studies in Indian coalfields is limited, mainly, due to two reasons: (1) uniqueness of the rock mass and (2) complex geo-mining conditions.

In absence of an indigenous design norm for a rib/snook, different field applications of the MD in Indian coalfields have adopted the previous reported methods for this purpose. Existing differences in the site conditions, however, made this adoption difficult. The reported design norms have considered, mainly, two extreme conditions of the roof strata and the presence of a narrow snook is found to be suitable [12] for both the conditions. However, in Indian coalfields, a large amount of coal seams are developed below moderate roof strata, which is not properly addressed in the reported studies. Further, field performance monitoring of these adopted designs in Indian coalfields noticed some successes [4] [5] and some failures [3][13]. Therefore, under the guidance of different available design norms and the field performance monitoring results, numerical modelling has been utilised to investigate the performance of a rib/snook under different varying conditions for the MD operations. An analysis of the simulation results, taking into consideration the results from field and laboratory studies, has been used to develop a preliminary model for the design of a rib/snook for the MD operations in Indian coalfields.

\subsection{Indian depillaring scenario}

Indian coalfields are known to encounter difficult overlying strata during underground mining [14]. But for a depillaring operation, both, highly laminated/weak and massive/strong overlying strata are termed as difficult because both of these conditions adversely interact with the broken nature of the conventional semi-mechanised depillaring. Reported poor efficiency [2] and safety [15] of the conventional depillaring operations for underground pillar extraction are considered by the Indian coal mining industry to phase-out this approach. A fully mechanised depillaring is however providing a faster rate of extraction [16] and improved safety along with increased production and productivity of a depillaring operation, which is obviously attractive for the coal mining industry of the country.

\subsection{Site conditions}

Underground extraction of the existing developed pillars by MD operation was first started at Anjan Hill Mine in 2003. Experiencing excellent performance of this approach [4] during the first field trial, at least, six different Indian mines have extensively used this approach for the depillaring. CSIR-CIMFR conducted extensive field investigations at four of these MD sites. On the basis of these investigations and published data of the other two MD sites [13][17], Table 1 gives a summary of these six MD operations in the coalfields. Depth of cover of these MD sites in the country varied from $60 \mathrm{~m}$ to $377 \mathrm{~m}$. The nature of overlying 
strata of these panels also varied widely: ranging from easily caveable and laminated roof of Pinoura Mine to massive and strong overlying strata of VK7 Mine. Caveability Index $(I)$ is one of the established approach for the assessment of the overlying strata [18], which is defined as:

$$
\mathrm{I}=\frac{\sigma \mathrm{l}^{\mathrm{n}} \mathrm{T}^{0.5}}{5}
$$

Where: $\sigma=$ Uniaxial Compressive Strength in $\mathrm{kg} / \mathrm{cm}^{2}$;

$1=$ Average length of core in $\mathrm{cm}$;

$\mathrm{T}=$ Thickness of the strong bed in $\mathrm{m}$ and the factor $n$ has a value of 1.2 in the case

of uniformly massive rocks with a weighted average of RQD of $80 \%$ and above. In all other cases $\mathrm{n}=1$.

An assessment of Caveability Index was performed to understand the nature of overlying strata through examination and testing of core samples of the different sites. Available geo-mechanical properties of the core-samples of overlying strata at Tandsi and Jhanjra are used for estimation of $I$ at these two sites. Fresh core samples of overlying strata were procured at VK-7, GDK-11, Anjan Hill and Pinoura mines. These procured core samples were tested in a laboratory for their physical and mechanical properties for estimation of $I$. The observed spectrum of $I$ for the mechanised depillaring sites is shown in Fig. 3.

\subsection{Field performance}

On the basis of the field performance studies, MD operations at Anjan Hill, Jhanjra and Pinoura are found to be, more or less, successful but not without difficulties. For example, in the first MD panel at Jhanjra, the left out ribs/snooks inhibited the caving of the moderate roof strata inside the goaf considerably with an advance of the working. This panel did not experience roof fall even after a goaf area exposure of more than $10000 \mathrm{~m}^{2}$ (Fig. 4). Under this condition, the working in the panel was stopped due to the apprehension of airblast. Taking advantage of shallow cover $(125 \mathrm{~m})$, the hanging roof strata inside the goaf is managed through long hole drilling and blasting from the surface [13].

Working below the easily caveable roof of Pinoura caused a number of roof falls and burial of the CM inside the cuts. During recovery of the $\mathrm{CM}$, the extent of fall was observed up to $20 \mathrm{~m}$ inside the roof but a left out rib of around $2 \mathrm{~m}$ width was found to be intact even against this height of the fall. But a roof fall of 5 to $6 \mathrm{~m}$ height only at VK-7 Mine (competent roof strata) caused crushing of a more than $4 \mathrm{~m}$ wide rib. This was the deepest MD panel in the county at around $377 \mathrm{~m}$ of cover. The MD at Tandsi Mine was practiced below 
incompetent roof strata at nearly $260 \mathrm{~m}$ depth of cover. Here, the MD experienced strata control problems at the goaf edge during full extraction resulting in adoption of a partial extraction method [17]. GDK 11 Incline Mine at around $325 \mathrm{~m}$ of cover witnessed extraction of total thickness of the seam $(6 \mathrm{~m})$ in single pass by the Continuous Miner (CM). The machine could win $4.6 \mathrm{~m}$ height directly, while $1.4 \mathrm{~m}$ floor coal is taken at final stage through ramp during the retreat. Again, here a mixed performance of the rib/snook was observed. Caving of the competent roof inside the goaf could not be inhibited by the left out ribs/snooks of increased height but, at a number of occasions, the roof fall encroached the working area.

\subsection{Available guidance}

The three popular rib/snook design approaches are based on: (a) width or width to height ratio (b) safety factor and (c) area of a rib/snook. As per DGMS circulars, a rib of 1.5 $\mathrm{m}$ width should be left against the goaf during a slicing operation of the depillaring in Indian coalfields. Further, this size of the left out rib should be judiciously reduced during retreat. Such circulars are for the convention depillaring only and there is mention about MD, where an uniform width of the rib/snook is difficult to be maintained. An analytical calculation by Van-der-Merwe (2005) found that the optimum rib/snook width may vary between 2.5 and 4 $m$ as per variation in the site conditions. Shepherd and Chaturvedula (1992) identified that width to height ratio $(\mathrm{w} / \mathrm{h})$ of the rib/snook is an important parameter for the design. Suggested range of $\mathrm{w} / \mathrm{h}$ for the rib/snook varied from 1 to 2 for different site conditions of the depillaring [10]. However, the shape issue makes it difficult to be applied for depillaring of the exiting square/rectangular pillars by CM. Safety factor based approach is adopted by Moolman and Canbulat (2003) [21] and recommended that the geometries and slice width of depillaring are varied for each depth until a safety factor of 0.35 is obtained for remnants (rib/snook) of a depillared pillar. This approach uses the conventional tributary area method for load estimation and Salamon and Munro (1967) [22] pillar strength formula for load bearing capacity of the snook/rib. Here, irregular shaped rib/snook makes it difficult to apply the conventional formula for the strength calculation and estimation of the load does not consider the influence of goaf.

Literature survey shows that, generally, an area-based design of a rib/snook is typically adopted [10] during depillaring of a square/rectangular pillar by CM. A major problem with the area-based design is length to width ratio. If this ratio is quite large/small then the validity of such a design may be compromised. However, this aspect of the design approach is automatically being taken care by the ability of the currently available CM for the MD. These CMs, generally, have a cut-out-distance (maximum length of cut inside the slice) 
equal to 11 to $12 \mathrm{~m}$ only. Therefore, wider pillars are split into fenders to fit the length of a rib/snook around this value of the cut-out-distance.

Relatively, high speed of extraction during the MD alleviates the magnitude of strata dynamics in and around a slicing operation but an understanding of interaction of the rib/snook with overlying strata is vital for its design. As per the basic design norm for a temporary support, the size of a rib/snook is not to be increased proportionately with depth of cover as it happens for a pillar. But, as per the above given field studies, the two major influencing factors for the area of a rib/snook during the MD are depth of cover and competency of the overlying strata. Different field trials of MD in Indian coal mines applied a variety of area of ribs/snooks ranging from $20 \mathrm{~m}^{2}$ to $125 \mathrm{~m}^{2}$ (Fig. 5) to cover the changing conditions of different sites. This range of the area of ribs/snooks is considered during the parametric study on simulated models.

\subsection{Parametric study}

Although size of a rib/snook is not to be increased proportionately with depth of cover as is the case for more conventional pillar design, field observations showed that depth of cover and competency of the overlying strata are the two major influencing factors for the area of a rib/snook. But a systematic field experimentation of varying these parameters for different sizes of the rib/snook would be difficult. Therefore a detailed parametric study for the rib/snook design is performed with numerical models to assess the impact of parameter variation on model performance.

\subsection{Numerical modelling}

A continuum analysis software package: FLAC $^{3 \mathrm{D}}$ [23] was untilised for numerical modelling of the varying rib/snook geometry. CSIR-CIMFR has successfully used this software [24] for different geo-technical investigations. Bedding planes are represented through interfaces, which are the main discontinuities of the proposed study. Rock Mass Rating (RMR) [25] evaluations of the varying strata was undertaken to compare site conditions. The Mohr-Coulomb Strain-hardening/Softening (MCSS) within FLAC ${ }^{3 \mathrm{D}}$ was chosen for the parametric study following comparison of initial depillaring results obtained through elastic and plastic models. Various strength and elastic properties, necessary for numerical modelling used in the strain softening model, are: (a) Elastic constants; (b) Peak and residual shear strength and the variation in between with the shear strain (c) Peak and residual angle of internal friction and the variation with the shear strain and (d) Angle of dilation and its variation with shear strain. The shear strength and friction angle were estimated using Sheorey's (1997) failure criterion for rock masses [26]. This criterion uses 
the 1976 version of RMR of Bieniawski [25] for reducing the laboratory strength parameters to give the corresponding rock mass values. This criterion is defined as:

$$
\sigma_{1}=\sigma_{\mathrm{cm}}\left(1+\frac{\sigma_{3}}{\sigma_{\mathrm{tm}}}\right)^{\mathrm{b}_{\mathrm{m}}}
$$

where,

$$
\begin{aligned}
& \sigma_{c m}=\sigma_{c} e^{\left(\frac{R M R-100}{20}\right)} \\
& \sigma_{t m}=\sigma_{t} e^{\frac{(R M R-100)}{27}} \\
& b_{m}=b^{\frac{R M R}{100}}
\end{aligned}
$$

$\sigma_{1}=$ Tri-axial strength of rock $\mathrm{m}$ ass $(\mathrm{MPa}), \sigma_{3}=$ Confining stress $(\mathrm{MPa}), \sigma_{c}=$ Compressive strength of intact rock $(\mathrm{MPa}), \sigma_{t}=$ Tensile strength of intact rock $(\mathrm{MPa}), b=$ exponent in failure criteria, which controls the curvature of triaxial curve, $\sigma_{c m}=$ Compressive strength of rock mass $(\mathrm{MPa}), \sigma_{t m}=$ Tensile strength of rock mass $(\mathrm{MPa})$ and RMR = Biniewiski's Rock Mass Rating. In the above equations, the subscript $m$ stands for the rock mass.

From laboratory testing, the value of the compressive strength $\left(\sigma_{c}\right)$ was known. Then the tensile strength $\sigma_{t}=\sigma_{c} / 15$ and $\mathrm{b}=0.5$ were taken as the most representative values, as seen from a large number of published test data [26].

The factor of safety $(S F)$ is defined as:

$$
\left.\begin{array}{ll}
S F=\frac{\sigma_{1}-\sigma_{3 i}}{\sigma_{1 i}-\sigma_{3 i}} & \text { for } \sigma_{3}<\sigma_{t} \\
S F=\frac{\sigma_{t}}{\sigma_{3}} & \text { for } \sigma_{3}>\sigma_{t}
\end{array}\right\}
$$

Where, $\sigma_{1 i}=$ Induced major principal stress $(\mathrm{MPa})$ and $\sigma_{3 i}=$ Induced minor principal stress $(\mathrm{MPa})$.

From these, the rock mass shear strength $\tau_{s m}$; the coefficient, $\mu_{0 m}$ and the angle of internal friction, $\phi_{0 m}$ are obtained as:

$$
\tau_{s m}=\left(\sigma_{c m} \sigma_{t m} \frac{b_{m}^{b_{m}}}{\left(1+b_{m}\right)^{1+b^{m}}}\right)^{1 / 2}
$$




$$
\begin{gathered}
\mu_{0 m}=\frac{\tau_{s m}^{2}\left(1+b_{m}\right)^{2}-\sigma_{t m}^{2}}{2 \tau_{s m} \sigma_{t m}\left(1+b_{m}\right)} \ldots \ldots \\
\phi_{0 m}=\tan ^{-1}\left(\mu_{0 m}\right) \ldots \ldots \ldots \ldots
\end{gathered}
$$

It was, however, found that the values of rock mass shear strength, $\tau_{s m}$ and friction angle, $\phi_{0 m}$ so determined had to be changed slightly to account for the fact that the MCSS Plasticity model in FLAC3D uses the linear Mohr- Coloumb criterion while the Sheorey criterion is nonlinear. The value of $\tau_{s m}$ obtained from the Sheorey criterion was increased by $10 \%$ and that of $\phi_{0 m}$ was reduced by $5^{\circ}$ to use them as Mohr-Coloumb parameters.

The MCSS model also requires parameters describing the rate of cohesion and/or friction drop as a function of plastic strain in the post-peak region. The determination of the MCSS parameters for a rock mass is a difficult task, but carried out empirically by performing back analysis. Different test pillar models were run with various sets of MCSS parameters for determination of pillar strength and compared with pillar strength value, calculated through an empirical formula. The best match was selected for the subsequent modelling of MD panel.

\subsection{Site details}

A parametric study within [26] can easily be performed by considering typical site conditions of the mining with hypothetical systematic variations in different parameters. However, assumptions for typical site conditions for underground coal mining can be difficult. Therefore, the actual site conditions of a representative MD are considered for the modelling within the current investigation. Accordingly, dimensions of the considered block for the modeling are $252 \mathrm{~m}, 252 \mathrm{~m}$ and $115 \mathrm{~m}$ along the $\mathrm{X}, \mathrm{Y}$ and $\mathrm{Z}$ directions respectively. Total $150 \mathrm{~m}$ width of the block is used for mining around a barrier of $51 \mathrm{~m}$ thickness. Height of the working is kept $4.0 \mathrm{~m}$ with a pillar size of $30 \mathrm{~m} \times 30 \mathrm{~m}$ (corner to corner) and gallery width equal to $6.0 \mathrm{~m}$. As usual, cubic and cuboids meshing are used for the formations of different mining structures in the model. Height of the simulated model is kept to be $59 \mathrm{~m}$ above the working the and thickness of the modelled floor below the working seam is kept to be $52 \mathrm{~m}$ only. Truncated Load $(\gamma \mathrm{H})$ is applied on the model as per actual depth cover of the coal seam. The interval of mesh is considered 0.5 meters in coal seam and 1 meter in the other layers. Different layers of this model, including the coal seam was simulated as per the observed column of stratigraphy (above and below the coal) through a coring bore-hole data 
of the site. The boundary condition in the numerical model has been defined in such a way that the vertical wall of the model in $\mathrm{X}$ and $\mathrm{Y}$ direction and the floor of the model in $\mathrm{Z}$ direction are fixed.

Physico-mechanical properties of coal and overlying/underlying rock strata are derived through field and laboratory testing of freshly procured core samples. Other required properties were estimated according to Murli Mohan et al. [24], as mentioned in Tables 3 and 4. In situ stress values were estimated as per Sheorey [27], which are given as:

$$
\begin{array}{ll}
\mathrm{S}_{\mathrm{v}}=0.025 \mathrm{H} & \mathrm{MPa} \\
\mathrm{S}_{\mathrm{h}}=\mathrm{S}_{\mathrm{H}}=2.4+0.01 \mathrm{H} & \mathrm{MPa}
\end{array}
$$

where, $\mathrm{H}=$ Depth of cover in metres, $\mathrm{S}_{\mathrm{v}}=$ Vertical in-situ stress, $\mathrm{S}_{\mathrm{h}}=$ Minor horizontal insitu stress and $\mathrm{S}_{\mathrm{H}}=$ Major horizontal in-situ stress.

\subsection{Simulation results}

The parametric study covered testing of nearly 250 models in laboratory. Stable size of a rib during slicing is studied for different stages of the depillaring for different values of depth of cover and CMRI-RMR [29] of overlying strata as given in Table 5. The CMRI-RMR value is taken as a parameter to study the effect of the nature of the immediate roof strata over the rib/snook size because this parameter is frequently used in Indian coal-fields for immediate roof categorisation. Size of the rib was varied for a chosen set of depth of cover and CMRI-RMR to find out a lower value of the stable size of rib/snook. As per the boundary conditions of the considered site and results of the field observations, the three sizes of the rib/snook considered for this investigation are: $42 \mathrm{~m}^{2}, 78 \mathrm{~m}^{2}$ and $114 \mathrm{~m}^{2}$ respectively. More variations in the sizes of ribs/snooks were not considered necessary as part of this initial investigation. Experimentations with these three sizes of ribs/snooks, showed that the size of a rib/snook needs to be fixed for a given site conditions (Fig. 6). Here stress concentration

over three different sizes of ribs/snooks shows that the smaller size rib/snook $\left(42 \mathrm{~m}^{2)}\right.$ has experienced considerable induced stress, even some failure in its thinner part, for $150 \mathrm{~m}$ depth of cover and 40 CMRI-RMR of the overlying strata. While the other two sizes of ribs/snooks $\left(78 \mathrm{~m}^{2}\right.$ and $\left.114 \mathrm{~m}^{2}\right)$ are, almost, relaxed for the same conditions of the site.

\subsection{Shape effect}

Mark and Zelanko [10] suggested a "method of slices" to estimate strength (bearing capacity) of an irregular shaped rib/snook. This method was suggested because it is difficult to use the existing pillar strength formulae to estimate the strength of a snook/rib due to its shape. They assumed that any pillar element is a function of its distance from the nearest pillar rib. They defined pillar stress function $\left(\sigma_{v}\right)$ as: 


$$
\sigma_{\mathrm{v}}=\mathrm{S}_{1}[0.64+2.16(x / h)]
$$

where, $\mathrm{S}_{1}=$ In situ coal strength, $\mathrm{x}=$ Distance from the nearest pillar rib, $\mathrm{h}=$ Pillar height. They also defined a parameter called "Stability Factor", which is a bearing capacity-to-load ratio of a rib/snook. It is suggested that a yielding snook should have a stability factor value equal to 2.5. On the basis of these assumptions they provided stress profiles over a rib/snook (Fig. 7).

Field studies found that an irregular shaped rib/snook encounters instability in its thinner portion after experiencing stress concentration due to increased width of the excavation. After sufficient increase in the width of the extraction in a simulated model, an observed typical failure of the thinner part and concentration of induced stress in the core of the rib/snook is shown in Fig. 8. This nature of the observed stress redistribution over a rib/snook during depillaring does not exactly match with that in different slices given by Mark and Zelanko [10]. Numerical modelling found that nearly one third length (thinner part) of the left out rib/snook does not provide much resistance to lowering of the roof strata. Symmetrical nature of the stress distribution over all along the area of an irregular shaped rib/snook is found to be difficult for the coal mass. Major part of the stress concentration takes place only in the wider part of the left out snook/rib. Mark and Zelanko's approach of stress profiling seems to be valid for an elastic material only.

Observed variation of stable rib/snook size with depth of cover and CMRI-RMR is shown in Fig. 9. It is observed that the moderate roof strata generate more loading over the rib/snook than the strong and weak roof strata. These observations, conducted for only three different sizes of the rib/snook, found that the design of rib/snook is more important for moderate roof strata than strong/massive or weak/laminated roof strata. Observed increase in the area of the stable rib/snook with depth of cover is, more or less, an accepted practice for the design. But an increase in the area of the stable rib/snook with CMRI-RMR in the beginning and then decease in the area of the stable rib/snook with CMRI-RMR is found to be interesting from strata mechanics point of view.

\subsection{Conceptual model}

It is difficult to cover all possible site conditions during a simulation study and, therefore, a practical bandwidth of the geo-mining conditions are considered for the parametric study using the numerical models. However, the obtained results can provide a good conceptual idea or guidelines regarding the rib/snook loading during the MD.

\subsection{Strata mechanics}


An attempt to develop a conceptual model for the rib/snook design on the basis of the stress distribution study on the simulated model requires an understanding of the strata mechanics phenomenon in and around a depillaring operation. A depillaring operation includes three important mining structures: (a) Pillar/fender, (b) goaf and (c) applied support. Left out ribs/snooks also work/perform like applied support for a depillaring operation. The response of these mining structures keeps changing with progress or during the life of the depillaring operation in a panel. In a depillaring panel, generally, the area around intact pillars (standing ahead of the extraction line) does not experience much strata dynamics. However the area, in and around the goaf, encounters considerable amount of strata dynamics and is the main source of stress redistribution over pillars ahead of the extraction line. Here, it is important to study the interaction between roof and pillars around the goaf edge under the existing site conditions. Generally, in the beginning of the pillar extraction, a beam of overlying strata (clamped at both ends) is formed over the goaf. After a sufficient increase in the dimension of the goaf, the beam of roof strata fails and a cantilever is formed at the goaf edge. Now, splitting/slicing work for the progress of the depillaring is done under the cover of this cantilever. Although the major load of the overhang is transferred to the solid pillars (standing around the goaf edge) at this situation, there is a possibility of local instability in the lower horizon of the cantilever due to the inherent nature of the formations. Therefore, the characteristic of the cantilever is, mainly, governed by the nature of the overlying strata. Here a systematic design and planning of rib/snook to control the local instability of the lower horizon of the cantilever (to cover the span over the proposed slice/slices for the depillaring) is important. Stress concentrations over a rib/snook, formed after one and four rows of pillar extractions, are shown in Fig. 10 to visualise the effect of progress of a depillaring operation. Observed nature and amount of stress concentration over three different sizes of ribs/snooks provide important guidance/guidelines for their design.

\subsection{Parametric co-relations}

The above mentioned literature review and field studies indicate that the design of a rib/snook is influenced by depth of cover and nature of the roof strata. Accordingly, an attempt is made to understand the influence of these two parameters on rib/snook design through different simulation results.

The numerical simulation study showed that the development of cuts under competent immediate roof strata caused, relatively, smaller load development over the neighbouring snook/rib (Fig. 11). Good competency of the roof strata might have securely covered the complete span over the slice/slices and most of the loads might have transferred to adjacent 
solid pillars/fenders. In case of moderate strata, there was a decline in the competency of roof over the span of slice/slices, which made it difficult to transfer the major overhanging load towards the solid pillar. A dilution in competency of the exposed roof strata over the slice/slices may induce deformation before the solid pillars/fenders, which might have developed more loads over the left out rib/snook. Therefore, the nature of deformation of the moderate roof strata and the width of slice/slices are, mainly, controlled by an efficient design of the snook/rib. In the presence of an extremely weak/laminated roof stratum a relatively smaller width/span of slice/slices is adopted and good settlement of overlying strata is observed inside the goaf. The observed extending nature of the competent roof strata is found to be absent here during its caving. This resulted in less load development over the neighbouring rib/snook. These observations show that the complete band width of moderate roof strata created a relatively higher load over the rib/snook in comparison to, both, extremely weak and strong roof strata.

As per results of the numerical modelling, there is an increase in the stable rib/snook (Fig. 9) size with an increase in depth of cover. This finding is not exactly in tune with the assumption that a rib/snook is like an applied support for a small period of time. However, it is an observed fact that a natural support-such as a pillar/fender experiences side spalling at deeper cover and the rib/snook is formed from these natural supports only. Under the side spalling condition, some area of the formed rib/snook may not be good resistive to the roof strata. Therefore, the observed increase in stable size of a rib/snook with depth of cover seems to be in tune with the existing site conditions.

Obtained stable sizes of ribs/snooks for different depth of cover and nature of the roof strata (in terms of CMRI-RMR) are subjected to a multivariate regression analysis. This analysis provided a relationship to estimate the stable size of the rib/snook $(\mathrm{S})$, which is given as:

$$
S=0.52 H^{0.74} R^{0.23} \mathrm{~m}^{2}
$$

where, $\quad \mathrm{H}=$ depth of cover, $\mathrm{m}$

\section{$\mathrm{R}=\mathrm{CMRI}-\mathrm{RMR}$}

It would be interesting to correlate CMRI-RMR with the caveability index to make the above mentioned findings of numerical models more useful in the field.

\subsection{Conceived model}

It is observed that the depth of cover and nature of roof strata affected the rib/snook size differently. Movement/caving of a strong/massive roof stratum is, mainly, governed by fender or pillar, while that of a weak/laminated stratum is controlled by the properties of the 
immediate roof and difficulty in generation of load over the rib/snook. It is moderate roof strata, which offers excessive loading to a rib/snook during the slicing operation of MD. An attempt is made to develop a conceptual model (Fig. 12) on the basis of the observed rib/snook size variations with the nature of immediate overlying strata. Presence of moderate roof strata induces considerable amount of load over the rib/snook. Therefore, relatively, larger sizes of ribs/snooks are required during MD under such type of roof strata in comparison to the weak or strong roof strata. However, at the time of retreat, there is a need to dilute the competency of these ribs/snooks by judicious reduction in their size for smooth caving of the roof strata inside the goaf.

\subsection{Conclusions}

Field performance studies of the adopted rib/snook design at different MD operations in Indian coalfields have provided mixed results. Position and shape of a rib/snook in MD make it difficult to apply a design approach based on width or estimation of strength to load ratio. Literature review finds an area-based approach for the design of an irregular shaped rib/snook is normally adopted but, generally, two extreme ends of the nature of roof strata are considered for this design. Results of the undertaken numerical simulation show that the band width of the moderate roof strata creates more loading over the rib/snook than either the strong/massive or weak/laminated roof strata. At a fixed depth of cover $150 \mathrm{~m}$, a rib size of 42 $\mathrm{m}^{2}$ is stable for 20 CMRI-RMR but the size of a stable rib increases to $78 \mathrm{~m}^{2}$ for 40 and 60 CMRI-RMR values and, finally, decreases to $42 \mathrm{~m}^{2}$ for 80 CMRI-RMR. Again for a fixed CMRI-RMR 40, stable sizes of rib varied from 42 to $114 \mathrm{~m}^{2}$ for 150 to $550 \mathrm{~m}$ depth of cover. Results of the numerical simulation do not support the conventional assumption about a rib/snook to work exactly like an applied support during the slicing operation. This finding of the simulation matches with field observations, where deterioration in the intactness of the outer portion of a pillar/fender is often noticed at higher depth of cover. Observed nature of variations in the area of a stable rib/snook under different types of the roof strata provide an interesting strata mechanics phenomenon, which helps in conceptualising an approach for the rib/snook design. On the basis of the results of the numerical modeling study, a conceptual model is presented for the design of a rib/snook in MD under varying geo-mining conditions.

\section{ACKNOWLEDGEMENTS}

The authors are obliged to Dr. P. K Singh, Director, CSIR-CIMFR, for his permission to publish this paper. Mr. Rakesh Kumar and Mr. Amit Kumar Singh of Thick seam mining and strata mechanics Department provided considerable help in field work. The co-operation 
provided by the management of different coal companies during the field study is thankfully acknowledged. The study reported in this paper is based on an in-house investigation funded by the CSIR-CIMFR. The views expressed in the paper are those of the authors, and not necessarily of the institute to which they belong.

\section{References}

[1] Dixit MP, Mishra K. A unique experience of on shortwall mining in Indian coal mining industry. In: Proceedings of $3^{\text {rd }}$ Asian Mining Congress. MGMI Kolkata; 22-25 January 2010. p. 25-37.

[2] Singh R, Mandal PK, Singh AK, Kumar R, Sinha A. Optimal underground extraction of coal at shallow cover beneath surface/subsurface objects: Indian practices. Int J Rock Mech Rock Engg 2008;41(3):421-44.

[3] Singh R, Mandal PK, Singh AK, Kumar R, Sinha A. Coal pillar extraction at deep cover: with special reference to Indian coalfields. Int J Coal Geol 2011;86(2-3):276-88.

[4] Leeming J. Joy introduce continuous miner: Technology into India. Coal International/ Mining and Quarry World 2003:203-206.

[5] Ram S, Kumar D, Singh AK, Kumar R, Singh AK, Singh R. Strata mechanics studies during mechanized depillaring under varying geo-mining conditions. Communicated to Journal South African Institute of Mining and Metallurgy, 2015.

[6] Ghasemi E, Ataei M, Shahriar K, Sereshki F, Jalali SE, Ramazanzadeh A. Assessment of roof fall risk during retreat mining in room and pillar coal mines. Int J Rock Mech Min Sci 2012;54 (2012):80-89.

[7] Singh AK, Singh R, Maiti J, Mandal PK, Kumar R. Assessment of mining induced stress development over coal pillars during depillaring. Int J Rock Mech Min Sci 2011;48(5):80518.

[8] Petho SZ, Selai C, Mashiyi D, Van-der-Merwe JN. Managing the geotechnical and mining issues surrounding the extraction of small pillars at shallow depths at Xstrata Coal South Africa. Journal of the South African Institute of Mining and Metallurgy 2012; 112:10518.

[9] Singh R, Mandal PK, Singh AK, Singh TN. Cable bolting based mechanised depillaring of a thick coal seam. Int J Rock Mech Min Sci 2001;38(2): 245-57.

[10] Mark C, Zelanko JC. Sizing of final stumps for safer pillar extraction. In: Proceeding of $20^{\text {th }}$ International Conference on Ground Control in Mining. Morgantown WV USA; 7-9 August 2001. p. 59-66. 
[11] Chase FC, Mark C, Heasley KA. Deep cover pillar extraction in the U.S.A. In: Proceedings of the $21^{\text {st }}$ international conference ground control in mining. Morgantown WV USA; 28-29 July 2002. p. 68-80.

[12] Lind GH. Key success elements of coal pillar extraction in New South Wales. Journal of the South African Institute of Mining and Metallurgy 2002; 102(4):199-05.

[13] Mishra AK, Mishra AK, Rout M. Blast induced caving from surface over continuous miner panel at a $110 \mathrm{~m}$ cover in an Indian Mine. Arabian Journal for science and Engineering 2013; 38(7):1861-70.

[14] Singh R, Singh TN, Dhar BB. Coal pillar loading for shallow mining conditions. Int J Rock Mech Min Sci Geomechs Abst 1996;33(8):757-68.

[15] Singh R. Staggered development of a thick coal seam for full height working in single lift by blasting gallery method. Int J Rock Mech Min Sci 2004; 41(5):745-59.

[16] Singh R, Ram S, Singh AK, Kumar R, Singh A K. Strata control investigations during fully mechanized coal pillar extraction in Indian coalfields. In: Proceedings of the $33^{\text {rd }}$ International Conference on Ground Control in Mining. Morgantown WV USA; 29-31 July 2014. p. 158-64.

[17] Oldroyd C, Bigby D, Leeming J, Meyer L. Successful Application of Rock Bolt Support and Mechanised Depillaring in Difficult Roof Conditions at Tandsi Mine, Western Coalfields, India. In: Proceedings of $25^{\text {th }}$ International Conference on Ground Control in Mining. Morgantown WV USA; 1-3 August 2006. p. 396-00.

[18] Sarkar SK, Singh B. Longwall Mining in India. Sunanda Sarkar, Dhanbad: 1985.

[19] Van-der-Merwe JN. Fundamental analysis of the interaction between overburden behaviour and snook stability in coalmines. The Journal of the South African Institute of Mining and Metallurgy 2005;105(1): 63-73.

[20] Shepherd J, Chaturvedula VL. Strata mechanics of pillar extraction goaf edges. In: Proceedings of $11^{\text {th }}$ International Conference On Ground Control in Mining. Wollongong Australia; 7-10 July 1992. p. 13-21.

[21] Moolman C, Canbulat I. Economic and safe extraction of pillars and associated reserves for each category identified in Task 1.8.1 using underground mining methods. In: Coaltech 2020, Task 2.5.2, Johannesburg South Africa; 2003. p. 101-05.

[22] Salamon MDG, Munro AH. A study of the strength of coal pillars, Journal of the South African Institute of Mining and Metallurgy 1967; 68: 68-78. 
[23] Itasca, FLAC (Fast Lagrangian Analysis of Continua), Version 4.0., Itasca Consulting Group Inc., Minneapolis, Minnesota, 55401, USA, 2000.

[24] Murali-Mohan G, Sheorey PR, Kushwaha A. Numerical estimation of pillar strength in coal mines. Int J Rock Mech Min Sci 2001; 38:1185-92.

[25] Bieniawski ZT. Rock mass classifications in rock engineering. In: Bieniawski Z. T. (ed.), Exploration for Rock Engineering, vol. 1, Balkema, Rotterdam; 1976: p. 97-06.

[26] Sheorey, PR. Empirical rock failure criteria. Balkema, Netherlands, 1997. p. 176.

[27]Coggan JS, Gao F, Stead D, Elmo D. Numerical modelling of the effects of weak immediate roof lithology on coal mine roadway stability. Int J Coal Geol 2012; 90-91:10009.

[28] Sheorey PR. A theory of in situ stress in isotropic and transversely isotropic rocks. Int J Rock Mech Min Sci Geomech Abst 1994; 31:23-34.

[29] Venkateswarlu V, Ghose AK, Raju NM. Rock mass classification for design of roof support - A statistical evaluation of parameters. Min. Sc. Tech. 1989; 8: 97-07.

\section{List of figures}

Fig. 1: Formation of irregular shaped rib/snook in two popular manners of pillar extraction:

(A) Single-pass extraction of total pillar and (B) Splitting and slicing.

Fig. 2: Splitting and slicing for straight line of extraction in a mechanised depillaring panel.

Fig. 3: Covered range of Caveability Index of overlying strata during different mechanised depillaring operations.

Fig. 4: Plan showing extracted area and left out ribs under overhanging roof strata (shaded portion) in CM1 panel of Jhanjhra Mine.

Fig. 5: A variation between rib/snook area and depth of cover obtained through field study.

Fig. 6: Stress development on different sizes of ribs/snooks at $150 \mathrm{~m}$ depth and 40 CMRIRMR after first row of extraction in the panel.

Fig. 7: (a) Stress distribution over a rib/snook (cross-section to the rib/snook core) and (b) Plan view of the stress distribution in different slices (after [10]).

Fig. 8: Typical failure of thinner part of the rib/snook and concentration of induced stress in the centre of the rib after four rows of the pillar extraction.

Fig. 9: Observed variations in the stable size of a rib/size (in numerical models) with depth of cover and CMRI-RMR.

Fig. 10: Plan view of stress concentrations over a rib/snook (of three different sizes) after one and four rows of pillar extractions. 
Fig. 11: Plan view of stress concentrations over a rib/snook of $42 \mathrm{~m}^{2}$ area at the goaf edge (after four rows of pillar extraction) under roof strata with CMRI-RMR values 20, 40, 60 and 80.

Fig. 12: A conceptual model for the rib/snook design under varying competency of the roof strata.

\section{List of tables}

Table 1: Summary of different MD operations in Indian coalfields.

Table 2: Incorporated variation of different parameters in the Mohr-Coulomb strainhardening/softening model.

Table 3: Elastic parameters of the rock-mass for the modelling.

Table 4: Physico-mechanical properties of the rock-mass for the modelling.

Table 5: Range of parameters considered for the modeling study. 


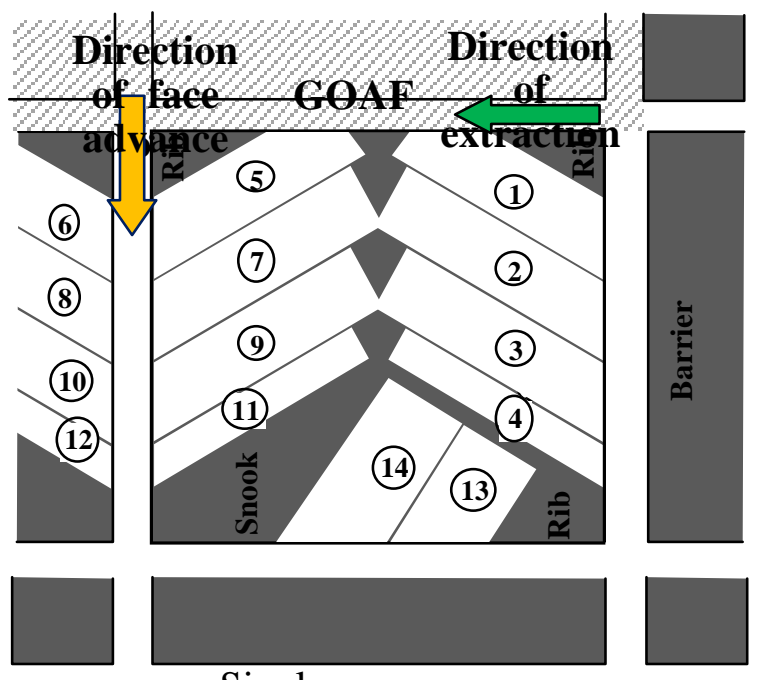

Single pass

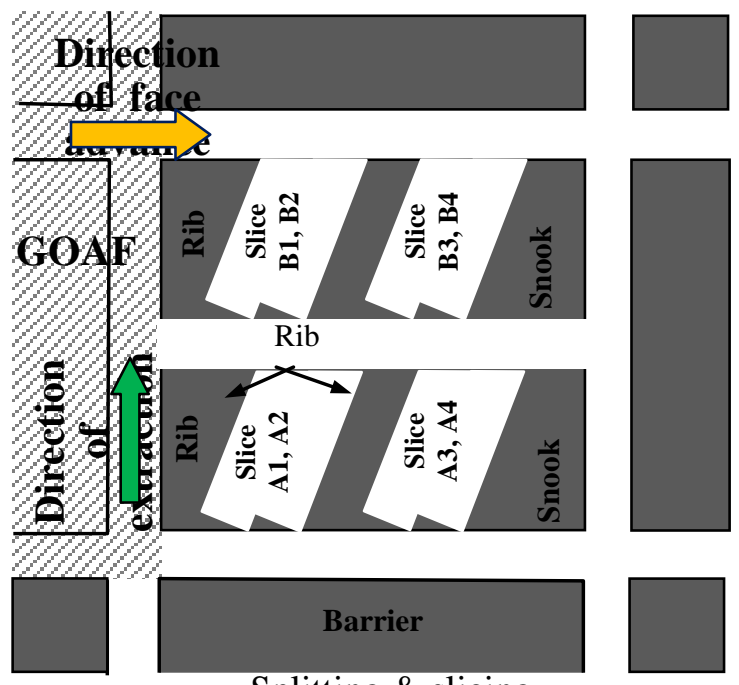

Splitting \& slicing

Fig. 1 : Formation of irregular shaped rib/snook in two popular manners of pillar extraction: (A) Single-pass extraction of total pillar and (B) Splitting and slicing.

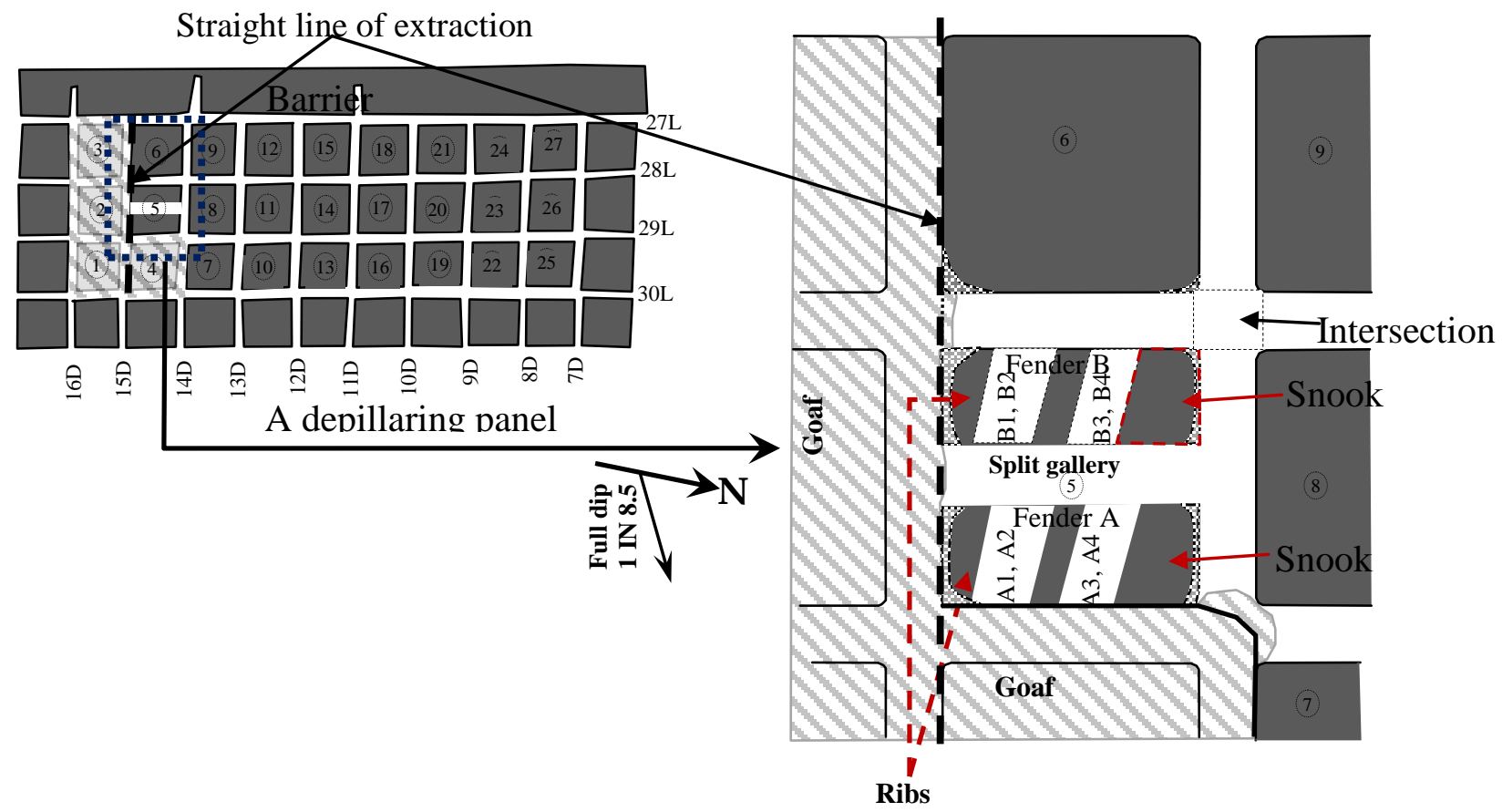

Fig. 2 : Splitting and slicing for straight line of extraction in a mechanised depillaring panel. 


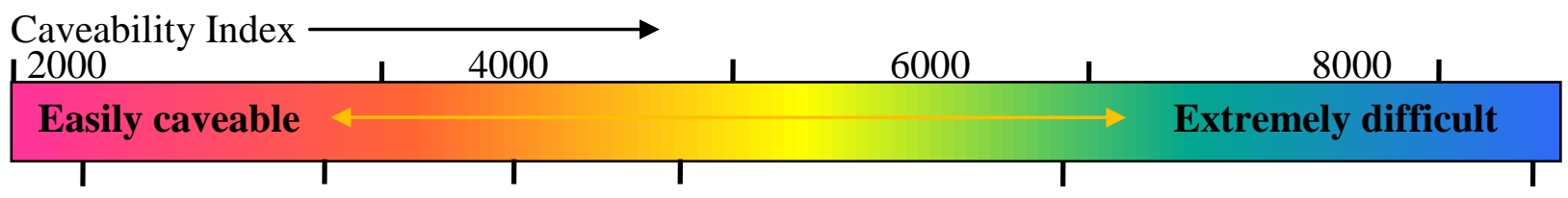

Fig. 3: Covered range of Caveability Index of overlying strata during different mechanised depillaring operations.

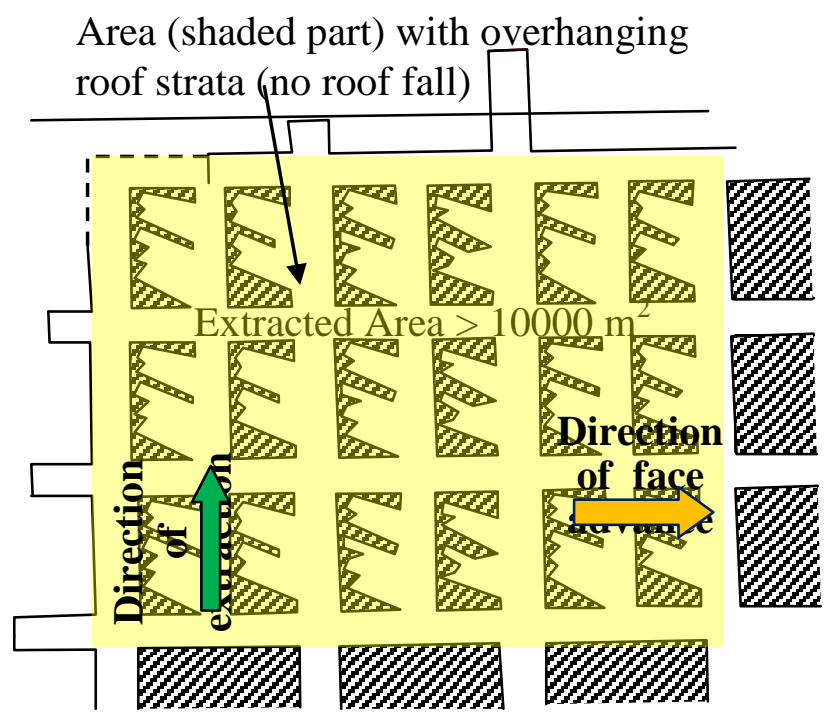

Fig. 4: Plan showing extracted area and left out ribs under overhanging roof strata (shaded portion) in CM1 panel of Jhanjhra Mine.

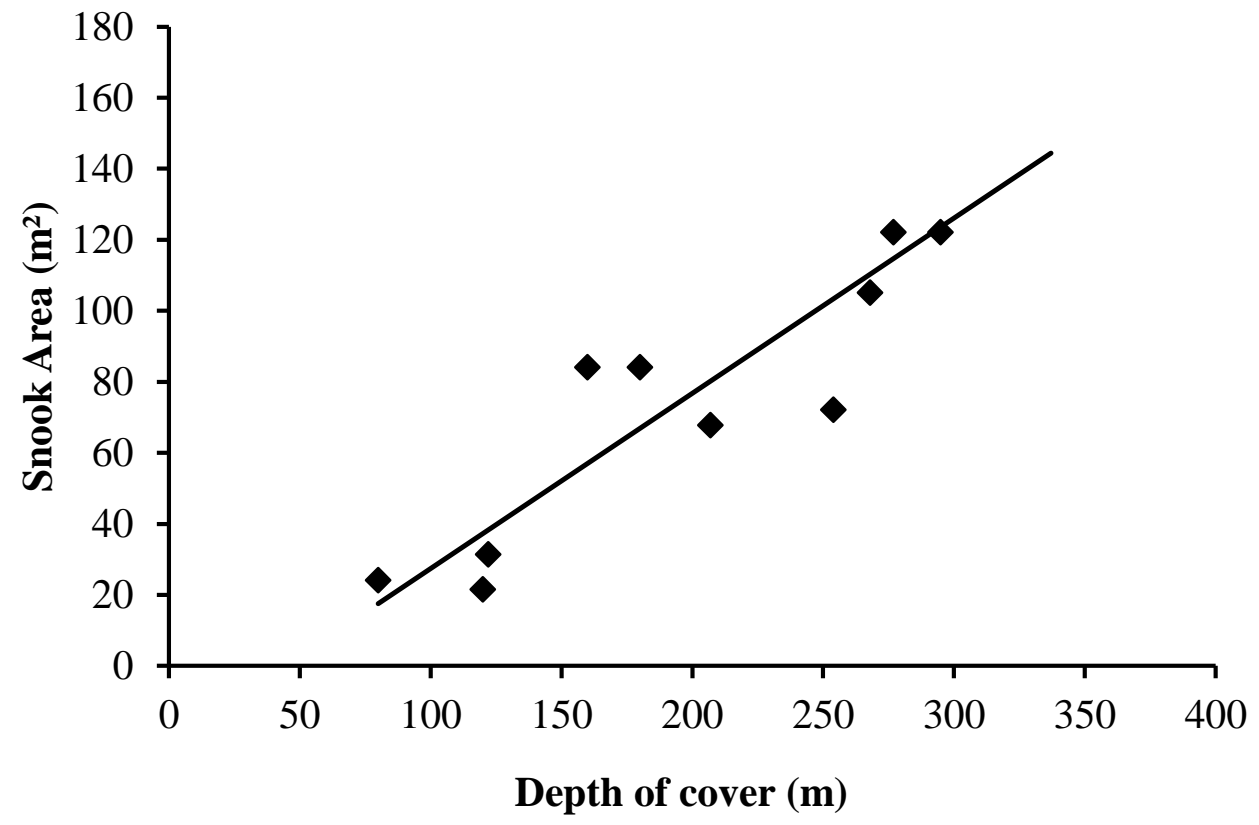

Fig. 5: A variation between rib/snook area and depth of cover obtained through field study. 


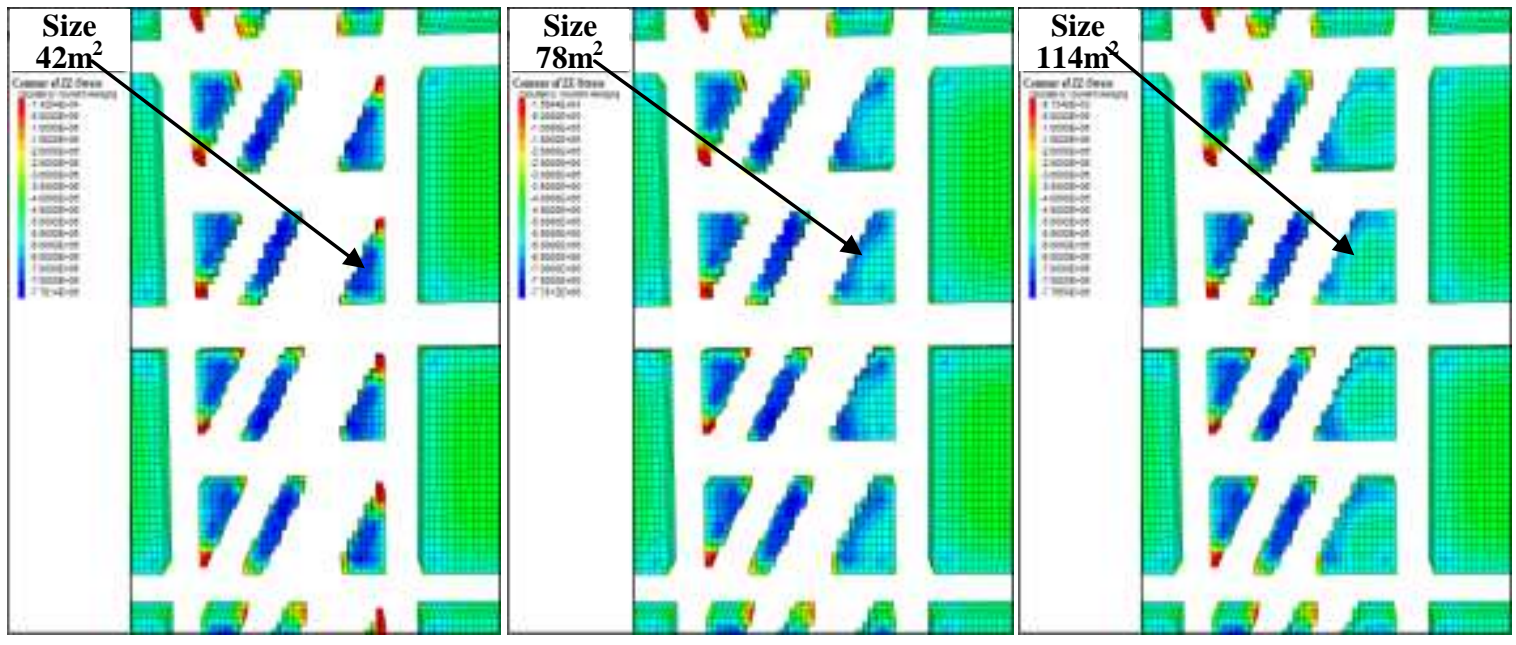

Fig. 6: Stress development on different sizes of ribs/snooks at $150 \mathrm{~m}$ depth and 40 CMRIRMR after first row of extraction in the panel.
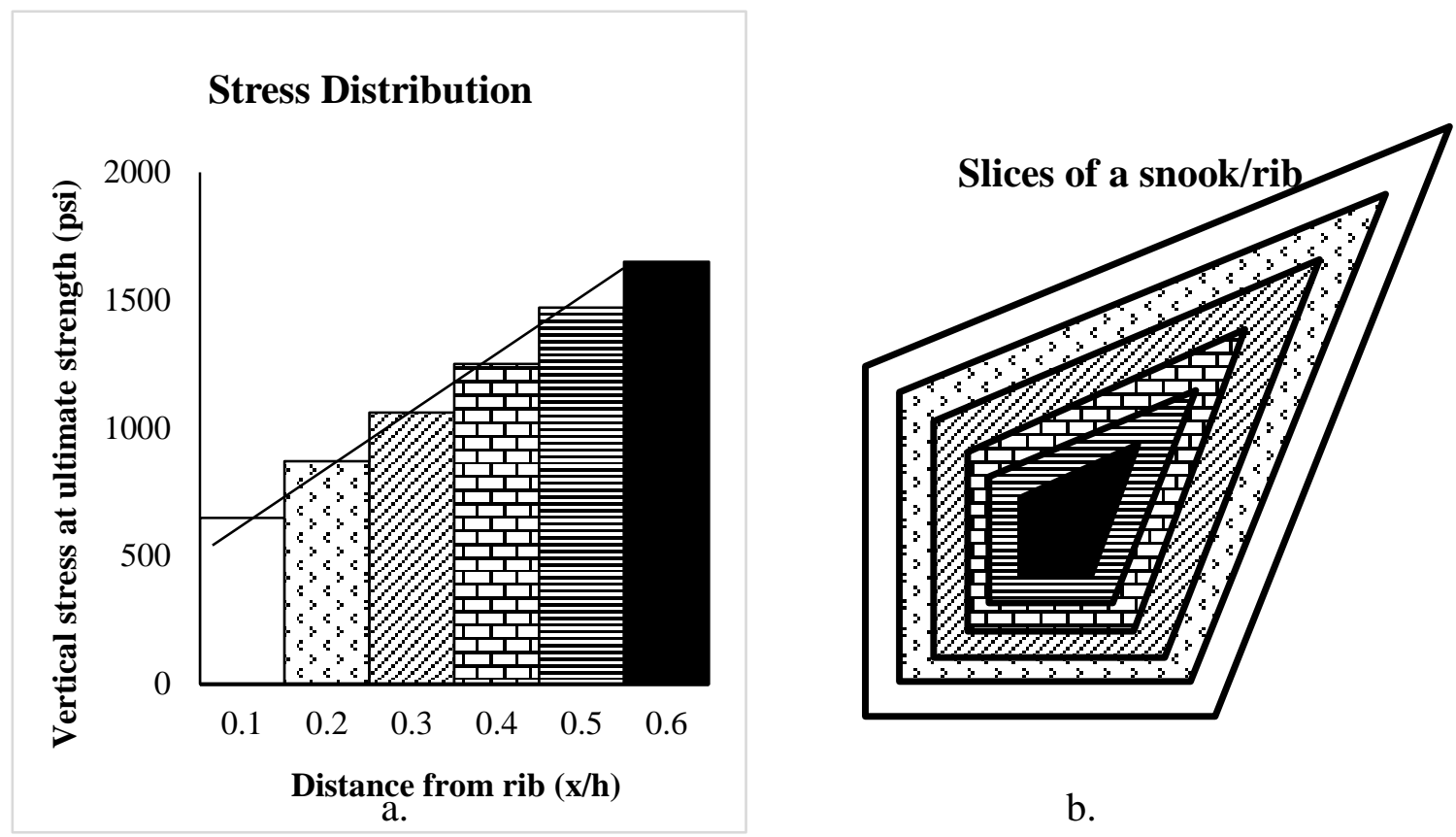

Fig. 7: (a) Stress distribution over a rib/snook (cross-section to the rib/snook core) and (b) Plan view of the stress distribution in different slices (after [10]). 


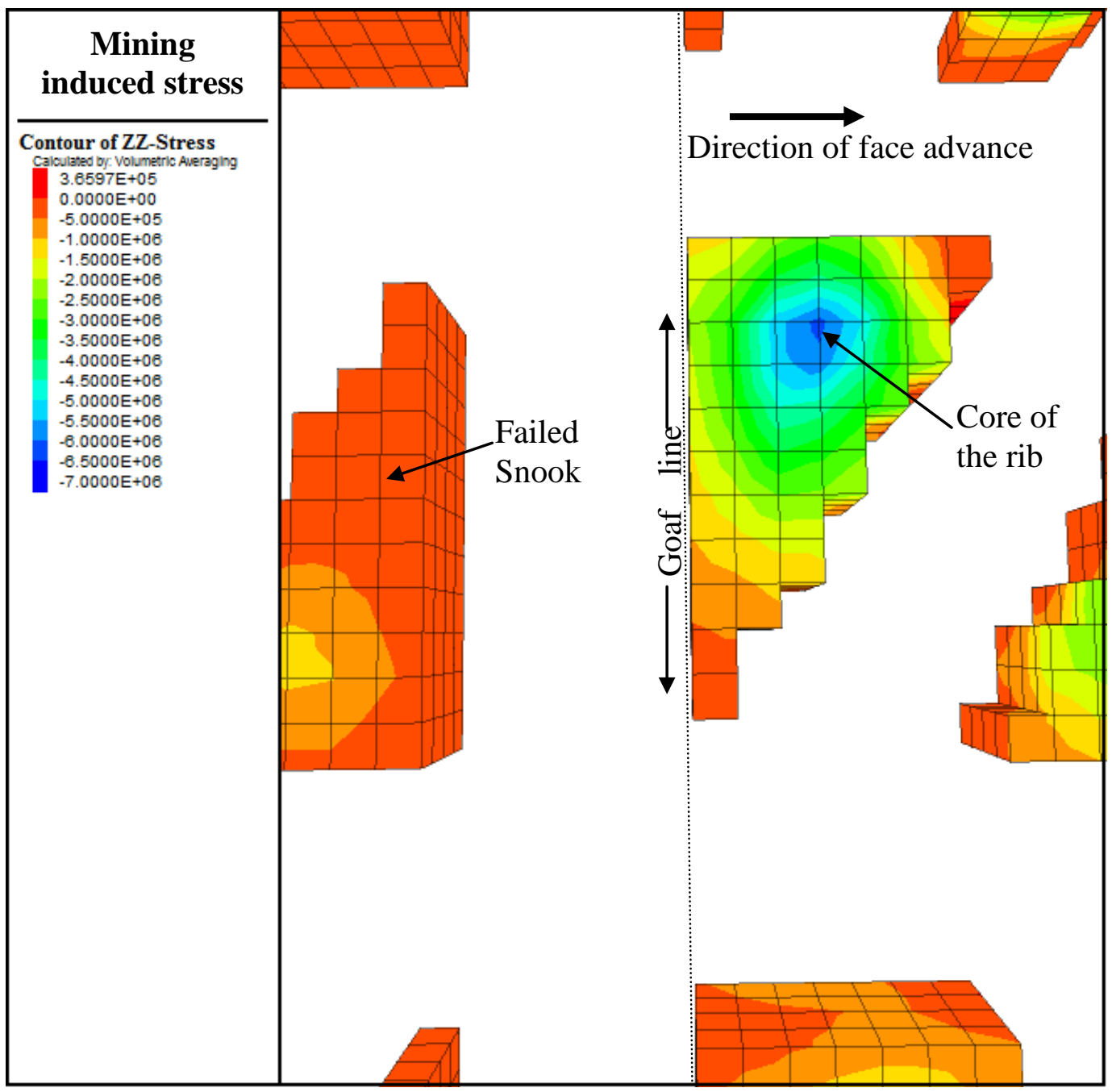

Fig. 8: Typical failure of thinner part of the rib/snook and concentration of induced stress in the centre of the rib after four rows of the pillar extraction. 

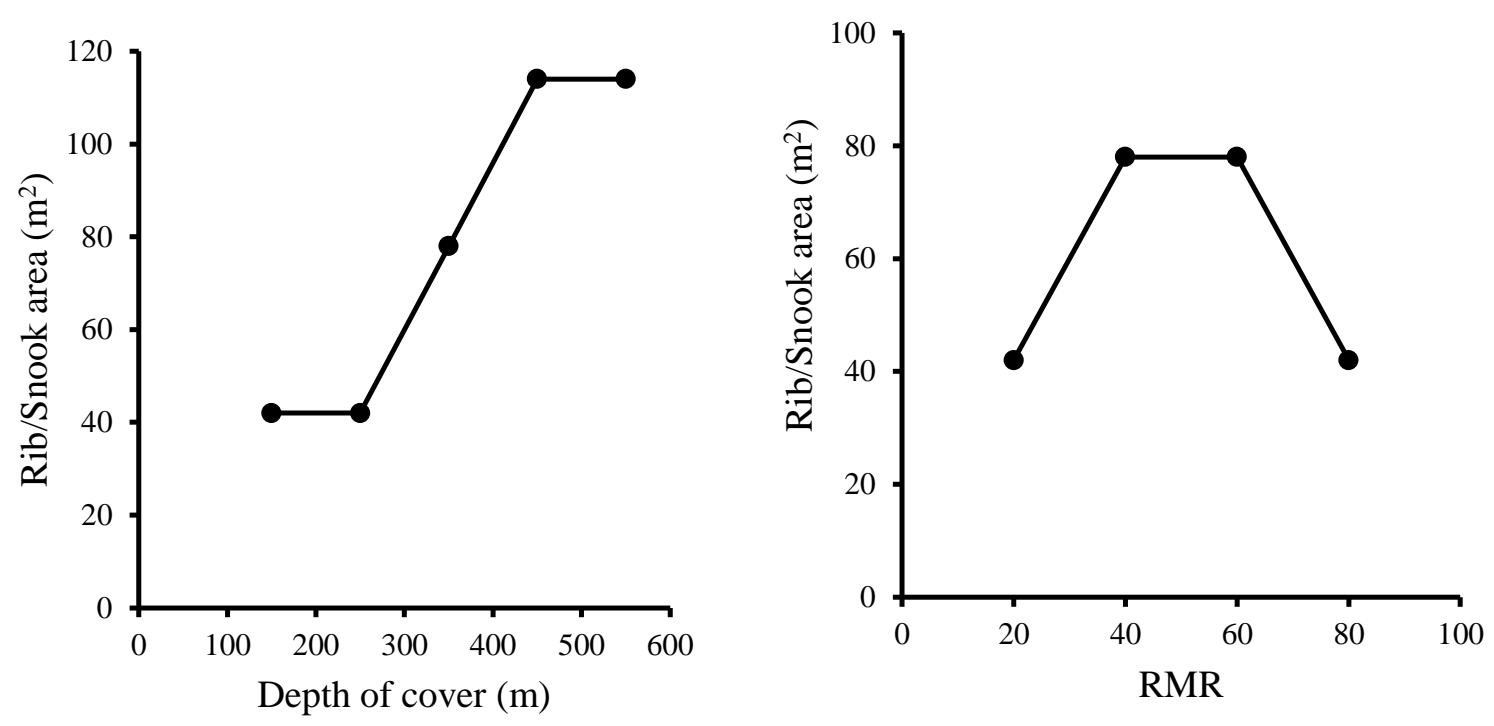

Fig. 9: Observed variations in the stable size of a rib/size (in numerical models) with depth of cover and CMRI-RMR. 


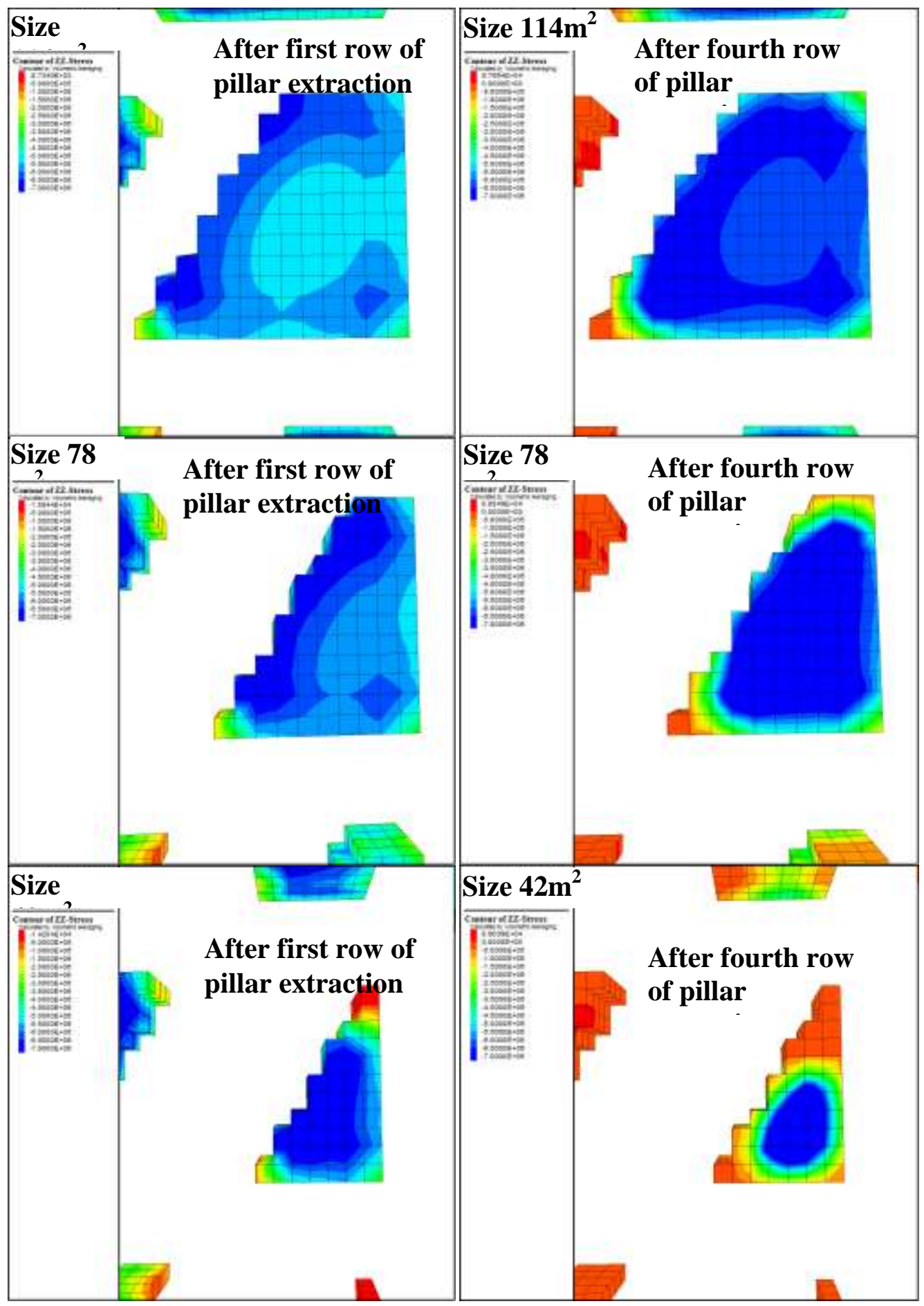

Fig. 10: Plan view of stress concentrations over a rib/snook (of three different sizes) after one and four rows of pillar extractions. 


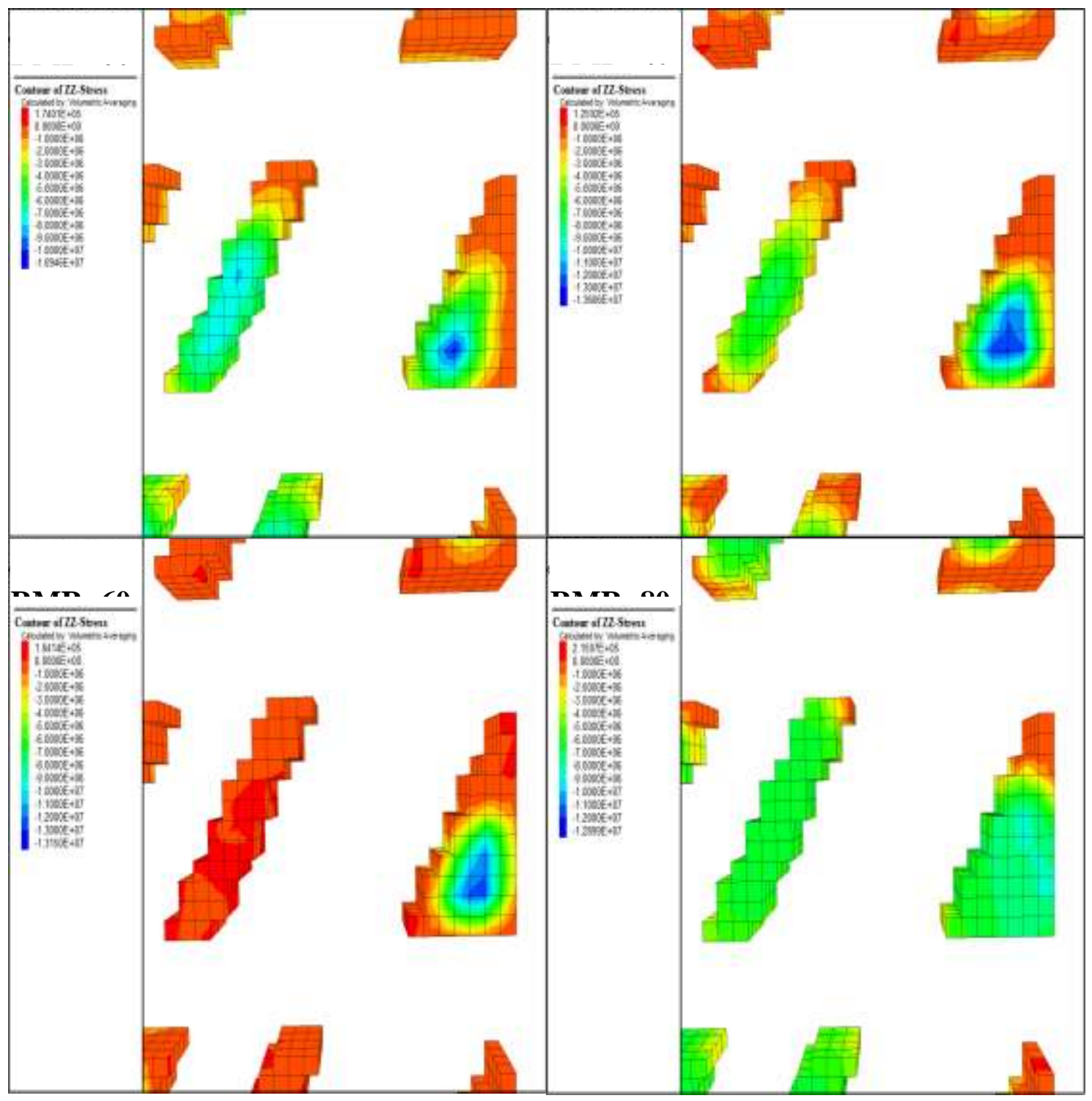

Fig. 11: Plan view of stress concentrations over a rib/snook of $42 \mathrm{~m} 2$ area at the goaf edge (after four rows of pillar extraction) under roof strata with CMRI-RMR values 20, 40, 60 and 80. 


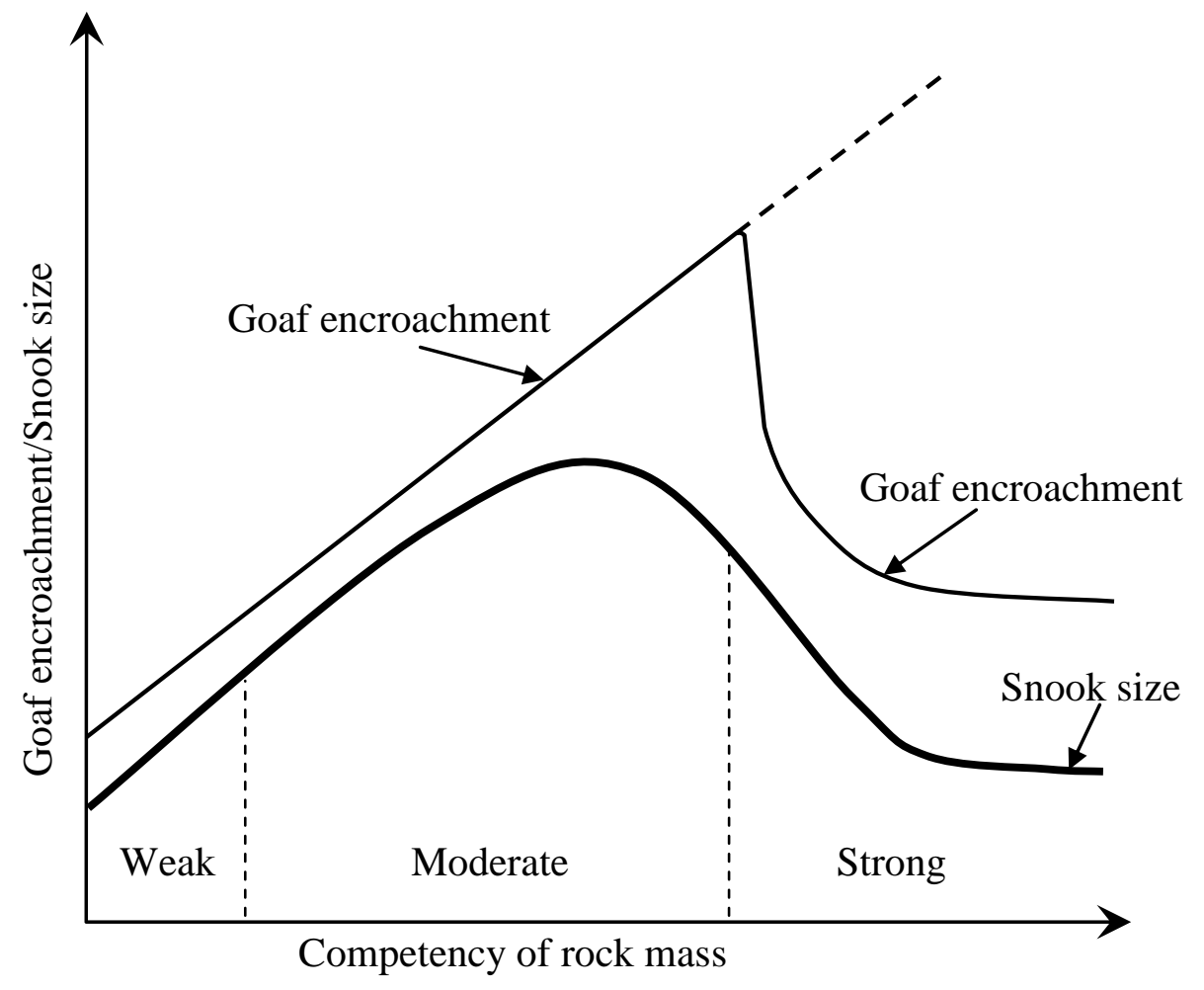

Fig. 12: A conceptual model for the rib/snook design under varying competency of the roof strata. 
Table 1: Summary of different MD operations in Indian coalfields.

\begin{tabular}{|c|c|c|c|c|c|c|c|c|}
\hline \multirow{3}{*}{$\begin{array}{l}\text { Name of } \\
\text { mine }\end{array}$} & \multicolumn{8}{|c|}{ Geo-mining parameters of different mechanized depillaring faces } \\
\hline & \multirow{2}{*}{$\begin{array}{l}\text { Dept } \\
\mathrm{h} \\
\text { cover } \\
, \mathrm{m}\end{array}$} & \multirow{2}{*}{$\begin{array}{l}\text { Pillar size, } \\
\text { (corner to } \\
\text { corner), m }\end{array}$} & \multirow{2}{*}{$\begin{array}{l}\text { Bord } \\
\text { width, } \\
\text { m }\end{array}$} & \multirow{2}{*}{$\begin{array}{l}\text { Working } \\
\text { height, } \\
\text { m }\end{array}$} & \multicolumn{2}{|c|}{ Overlying strata } & \multirow{2}{*}{$\begin{array}{l}\text { Manner } \\
\text { of } \\
\text { extraction }\end{array}$} & \multirow{2}{*}{$\begin{array}{l}\text { Performance } \\
*\end{array}$} \\
\hline & & & & & I & $\begin{array}{l}\text { Nature of } \\
\text { caving }\end{array}$ & & \\
\hline Pinoura & 60 & $\begin{array}{ll}18.5 & \mathrm{x} \\
19.5 & \end{array}$ & 6.5 & 3.0 & 2332 & Easily & $\begin{array}{l}\text { Single } \\
\text { pass }\end{array}$ & Success \\
\hline $\begin{array}{l}\text { Anjan } \\
\text { Hill }\end{array}$ & 85 & $\begin{array}{l}28.2 \\
28.2\end{array}$ & 6.6 & 4.5 & 4762 & $\begin{array}{l}\text { Moderate } \\
\text { to difficult }\end{array}$ & $\begin{array}{l}\text { Splitting } \\
\text { \& slicing }\end{array}$ & Success \\
\hline Jhanjra & 125 & $\begin{array}{l}26.0 \\
26.0\end{array}$ & 6.0 & 4.2 & 5672 & $\begin{array}{l}\text { Moderate } \\
\text { to difficult }\end{array}$ & $\begin{array}{l}\text { Splitting } \\
\& \text { slicing }\end{array}$ & $\begin{array}{l}\text { Delayed } \\
\text { caving }\end{array}$ \\
\hline VK-7 & 377 & $\begin{array}{l}40.0 \\
40.0\end{array}$ & 5.0 & 4.6 & 10522 & $\begin{array}{l}\text { Extremely } \\
\text { difficult }\end{array}$ & $\begin{array}{l}\text { Splitting } \\
\text { \& slicing }\end{array}$ & Roof collapse \\
\hline Tandsi & 260 & $\begin{array}{l}40.0 \\
40.0\end{array}$ & 5.0 & 3.0 & 3879 & $\begin{array}{l}\text { Unstable } \\
\text { roof strata }\end{array}$ & $\begin{array}{l}\text { Splitting } \\
\text { \& slicing }\end{array}$ & $\begin{array}{l}\text { Partial } \\
\text { extraction }\end{array}$ \\
\hline GDK-11 & 325 & $\begin{array}{lll}48 & .0 & x \\
46.0 & & \end{array}$ & 6.0 & $4.6-6.0$ & 7798 & Difficult & $\begin{array}{l}\text { Splitting } \\
\& \text { slicing }\end{array}$ & Success \\
\hline
\end{tabular}

*Performance of different depillaring operation, mentioned in this column, is as per field observations of production, productivity and safety.

Table 2: Incorporated variation of different parameters in the Mohr-Coulomb strainhardening/softening model.

\begin{tabular}{|l|l|l|l|}
\hline $\begin{array}{l}\text { Shear } \\
\text { strain }\end{array}$ & $\begin{array}{l}\text { Cohesion } \\
\left(\tau_{s m}\right) \\
(\mathrm{MPa})\end{array}$ & $\begin{array}{l}\text { Friction } \\
\text { angle } \\
\left(\phi_{0 m}\right)\left(^{\circ}\right)\end{array}$ & $\begin{array}{l}\text { Dilation } \\
\text { angle } \\
(\psi)\left({ }^{\circ}\right)\end{array}$ \\
\hline 0.000 & $1.1 \tau_{s m}$ & $\phi_{0 m}-5$ & 15 \\
\hline 0.005 & $1.1 \tau_{s m} / 5$ & $\phi_{0 m}-7.5$ & 5 \\
\hline 0.01 & 0 & $\phi_{0 m}-10$ & 0 \\
\hline 0.500 & 0 & $\phi_{0 m}-10$ & 0 \\
\hline
\end{tabular}


Table 3: Elastic parameters of the rock-mass for the modelling.

\begin{tabular}{|l|c|c|c|c|c|}
\hline \multicolumn{1}{|c|}{ Strata } & $\begin{array}{c}\text { Thickness } \\
(\mathrm{m})\end{array}$ & $\begin{array}{l}\text { Young's } \\
\text { modulus } \\
(\mathrm{GPa})\end{array}$ & $\begin{array}{l}\text { Shear } \\
\text { modulus } \\
(\mathrm{GPa})\end{array}$ & $\begin{array}{l}\text { Bulk } \\
\text { modulus } \\
(\mathrm{GPa})\end{array}$ & $\begin{array}{l}\text { Poisson's } \\
\text { ratio }\end{array}$ \\
\hline Floor: mgsst & 50.00 & 5.70 & 2.28 & 3.80 & 0.25 \\
\hline Coal seam & 6.00 & $2.00,3.00$ & 1.20 & 2.00 & 0.25 \\
\hline Roof Layer 1: mgsst\# & 0.5 & 7.00 & 2.80 & 4.67 & 0.25 \\
\hline Roof Layer 2:mgsst\# & 1.50 & 5.25 & 2.10 & 3.50 & 0.25 \\
\hline Roof Layer 3: cgsst\#\# & 6.00 & 4.80 & 1.92 & 3.20 & 0.25 \\
\hline Roof Layer 4: shale & 1.00 & 5.70 & 2.28 & 3.80 & 0.25 \\
\hline Roof & 50 & 4.80 & 1.92 & 3.20 & 0.25 \\
\hline
\end{tabular}

\# mgsst: Medium grained sandstone, \#\#cgsst: Coarse grained sandstone

Table 4: Physico-mechanical properties of the rock-mass for the modelling.

\begin{tabular}{|l|c|c|c|c|c|}
\hline \multicolumn{1}{|c|}{ Strata } & $\begin{array}{c}\text { Density } \\
\text { 3 } \\
(\mathrm{Kg} / \mathrm{m})\end{array}$ & $\begin{array}{c}\text { Cohesion } \\
(\mathrm{MPa})\end{array}$ & $\begin{array}{l}\text { Friction } \\
\text { angle } \\
\text { (Degree) }\end{array}$ & $\begin{array}{l}\text { Uniaxial } \\
\text { compressive } \\
\text { strength (MPa) }\end{array}$ & $\begin{array}{l}\text { Tensile } \\
\text { strength } \\
(\mathrm{MPa})\end{array}$ \\
\hline Floor: mgsst & 2310 & 2.17 & 37.44 & 55.80 & 3.72 \\
\hline Coal seam & 1400 & 0.78 & 36.50 & 32.00 & 2.10 \\
\hline Roof Layer 1: mgsst\# & 2500 & 2.43 & 39.23 & 60.60 & 4.83 \\
\hline Roof Layer 2:mgsst\# & 2210 & 1.38 & 34.88 & 53.50 & 3.50 \\
\hline Roof Layer 3: cgsst\#\# & 2310 & 0.85 & 42.73 & 38.20 & 2.54 \\
\hline Roof Layer 4: shale & 2310 & 2.43 & 39.23 & 60.60 & 4.83 \\
\hline Roof & 2310 & 2.17 & 37.44 & 55.80 & 3.72 \\
\hline
\end{tabular}

\#mgsst: Medium grained sandstone, \#\#cgsst: Coarse grained sandstone 
Table 5: Range of parameters considered for the modeling study.

\begin{tabular}{|c|c|c|}
\hline \multicolumn{2}{|c|}{} & Area of rib/snook $\left(\mathrm{m}^{2}\right)$ \\
\hline Depth (m) & CMRI-RMR & $42,78,114$ \\
\hline 150 & $20,40,60,80$ & $42,78,114$ \\
\hline 250 & $20,40,60,80$ & $42,78,114$ \\
\hline 350 & $20,40,60,80$ & $42,78,114$ \\
\hline 450 & $20,40,60,80$ & $42,78,114$ \\
\hline 550 & $20,40,60,80$ & \\
\hline
\end{tabular}

